\title{
Elevated Expression of Type II Na+ Channels in Hypomyelinated Axons of shiverer Mouse Brain
}

\author{
Ruth E. Westenbroek, ${ }^{1}$ Jeffrey L. Noebels, ${ }^{2}$ and William A. Catterall ${ }^{1}$ \\ 'Department of Pharmacology, University of Washington, Seattle, Washington 98195 and 2 Developmental Neurogenetics \\ Laboratory, Section of Neurophysiology, Department of Neurology, Baylor College of Medicine, Houston, Texas 77030
}

\begin{abstract}
Type I and type III $\mathrm{Na}^{+}$channels are localized mainly in neuronal cell bodies in mouse brain. Type II channels are preferentially localized in unmyelinated fiber tracts but are not detectable in normally myelinated fibers. In shiverermice, which lack compact myelin due to a defect in the myelin basic protein gene, elevated expression of type II $\mathrm{Na}^{+}$channels was observed in the hypomyelinated axons of largecaliber fiber tracts such as the corpus callosum, internal capsule, fimbria, fornix, corpus medullare of the cerebellum, and nigrostriatal pathway by immunocytochemical analysis with subtype-specific antibodies. No difference was observed in the localization of type I and type III $\mathrm{Na}^{+}$channels between wild-type and shiverer mice. These findings support the hypothesis that type II Na+ channels are preferentially localized in axons of brain neurons and suggest that their density and localization are regulated by myelination. The selective increase in the number of type II channels in hypomyelinated fiber tracts may contribute to the hyperexcitable phenotype of the shiverer mouse.
\end{abstract}

The autosomal recessive mutant mouse shiverer exhibits a severe deficit in myelination within its CNS (Bird et al., 1978; Rosenbluth, 1980b; Chernoff, 1981). Electron microscopic studies reveal that many axons are unmyelinated (Privat et al., 1979; Kirschner and Ganser, 1980; Rosenbluth, 1980b). Where myelination does occur, it is reduced in amount, is variable in compactness, and lacks the major dense line thought to be formed by myelin basic protein (Privat et al., 1979). In contrast, the myelin sheaths in the PNS are only slightly abnormal in these animals (Rosenbluth, 1980a; Peterson and Bray, 1984). The deficit in myelination results from a low level of myelin basic protein (Dupouey et al., 1979; Bourre et al., 1980; Kirschner and Ganser, 1980; Barbarese et al., 1983) due to a deletion of five exons of the myelin basic protein gene (Roach et al., 1985; Molineaux et al., 1986; Readhead et al., 1987).

\footnotetext{
Reccived Nov, 5, 1991; reviscd Jan. 3, 1992; acceptcd Jan. 13, 1992.

We are grateful to Ms. Anita Colvin and Dr. Karen DeJongh of the Molecular Pharmacology Facility, University of Washington, for peptide synthesis, to Dr. Concepcion Warner for antibody production, and to Mr. Rick Walsh for secretarial assistance. This work was supported by a National Multiple Sclerosis Society fellowship to R.E.W., by NIH Research Grants RO-1 NS25704 and PO-1 NS20482 (P. Schwartzkroin, P. I.) to W.A.C., and by a March of Dimes/Birth Defects Foundation research grant and a Pew Biomedical Scholars Award to J.L.N.

Correspondence should be addressed to William A. Catterall, Ph.D., Professor and Chair, Department of Pharmacology, SJ-30, University of Washington, Seattle, WA 98195.
}

Copyright $(C) 1992$ Society for Neuroscience $0270-6474 / 92 / 122259-09 \$ 05.00 / 0$
The reduced myelination in the shiverer mice causes a hyperexcitable phenotype with tremor and seizures but normal motor strength. Evidently, impulse conduction in central axons is retained, and the loss of myelination causes hypomyelinated axons to serve as ectopic foci for abnormal electrical activity. Noebels et al. (1991) have recently demonstrated using ${ }^{3} \mathrm{H}$-saxitoxin binding methods that the number of $\mathrm{Na}^{+}$channels is increased in the large-caliber fiber pathways in the brain of the shiverer mouse. These results suggest a direct trophic role of myelin in the regulation of axonal $\mathrm{Na}^{+}$channel density and raise the possibility that this glial-neuronal interaction may differentially modulate the expression of individual $\mathrm{Na}^{+}$channel subtypes.

Four distinct $\mathrm{Na}^{+}$channel $\alpha$-subunits from rat brain, designated types I, II, IIA, and III, have been characterized by cDNA cloning and sequencing (Noda et al., 1986; Auld et al., 1988; Kayano et al., 1988). $\mathrm{Na}^{+}$channel types I, II, and IIA account for more than $85 \%$ of $\mathrm{Na}^{+}$channels in most regions of adult rat brain, while type III $\mathrm{Na}^{+}$channels are primarily expressed in fetal and neonatal animals (Gordon et al., 1987; Beckh et al., 1989; Sarao et al., 1991; Yarowski et al., 1991). Immunocytochemical localizatition of $\mathrm{Na}^{+}$channel subtypes in rat CNS has revealed a preferential localization of type I $\mathrm{Na}^{+}$channels in cell bodies and type II channels in unmyelinated axons (Westenbroek et al., 1989). This differential expression and localization of $\mathrm{Na}^{+}$channel subtypes led us to investigate the localization of $\mathrm{Na}^{+}$channel types I, II, and III in shiverer mice to determine which of the subtypes is responsible for the observed increase in $\mathrm{Na}^{+}$channel density in the hypomyelinated central fiber tracts.

\section{Materials and Methods}

Synthetic peptides. Peptide SP32 ${ }_{\text {III }}$ (KYHLEGNHRADGDRFP), corresponding to residues $511-524$ of the $\alpha$-subunit of $\mathrm{Na}^{+}$channel type III plus N-terminal lysine and tyrosine extensions, was synthesizcd by the solid-phase method (Merrifield, 1963) and purified by reversedphase HPLC on a Vydac $218 \mathrm{TP} 10$ column. The identity of the purified peptide was verified by amino acid analysis. Peptide SP $11_{1}$, corresponding to residues $465-481$ of type I, peptide $S P 11_{\mathrm{II}}$, corresponding to residues $465-484$ of type II, and peptide SP20, corresponding to residues 1 106-1125 of the $\alpha$-subunit of rat brain $\mathrm{Na}^{+}$channel type II, have been previously described (Gordon et al., 1987; Westenbroek et al., 1989).

Preparation of antibodies. Production of antibodies against peptides SP1 $1_{1}\left(\mathrm{Ab}_{\mathrm{SPI} 1-\mathrm{I}}\right)$ and SP1 $1_{\mathrm{II}}\left(\mathrm{Ab}_{\mathrm{SP} 11-\mathrm{II}}\right)$, which recognize the type I and type II $\mathrm{Na}^{+}$channels, respectively, has been described along with their affinity purification by adsorption to immobilized $\mathrm{Na}^{+}$channels (Gordon et al., 1987). Likewise, production and purification of antibodies to SP20 $\left(\mathrm{Ab}_{\mathrm{SP} 20}\right)$, which corresponds to a conserved region of type $\mathrm{I}$, type II, and type III $\mathrm{Na}^{+}$channels, has been reported (Westenbrock et al., 1989). The purified peptide SP32 ${ }_{\text {III }}$ was coupled through amino groups to bovine serum albumin using glutaraldehyde (Orth, 1979), 
dialyzed against PBS, emulsified in an equal volume of Freund's com plete (initial injection) or incomplete adjuvant (subsequent injections), and injected in multiple subcutaneous sites on New Zealand White rabbits at 3 week intervals. After the second injection, the antisera were collected and tested by radioimmunoassay (Costa and Catterall, 1984). Antibodies to SP32 $2_{\text {III }}\left(\mathrm{Ab}_{\mathrm{SP} 32-\mathrm{III}}\right)$ were purified by affinity chromatography on a CNBr-activated Sepharose column to which SP32 2 peptide had been previously coupled.

Immunocytochemistry. Brains from six or more young adult shiverer or wild-type mice (obtained from the breeding colony at Baylor College of Medicine) were examined using each antiserum. A detailed description of the procedures for fixation and immunocytochemistry using $A b_{S P 11-1}, A b_{S P 11-11}$, and $A b_{S P 20}$ have been previously reported. Similar procedures for the $A b_{S P 32-I I I}$ were carried out in this study. Briefly, the animals were anesthetized with sodium pentabarbital and perfused by intracardial cannulation with a solution of 4\% PLP (for details, see Westenbroek et al., 1989). The brains were immediately removed from the cranium and postfixed by immersion in fixative for either 30 min for $A b_{\text {SPI1-I }}$ or $2 \mathrm{hr}$ for $A b_{\mathrm{SP} 11-1 \mathrm{I}}, \mathrm{Ab}_{\mathrm{SP} 20}$, and $A b_{\mathrm{SP} 32-\mathrm{III}}$. The brains were then successively sunk in $10 \%, 20 \%$, and $30 \%(\mathrm{w} / \mathrm{v})$ solutions of sucrose in $0.1 \mathrm{~m}$ sodium phosphate buffer $(\mathrm{PB})$ at $4^{\circ} \mathrm{C}$. Frozen sagittal sections $(35 \mu \mathrm{m})$ were cut on a sliding microtome.

Free-floating sections were then processed for immunocytochemistry using the indirect PAP technique of Sternberger (1979) in combination with the above four antibodies. Prior to incubation, sections were washed in PB overnight and then treated with a series of alcohols and methanol to delipidate the tissue and quench endogenous peroxidase activity, respectively (see Westenbroek et al., 1989, for details). Sections were then incubated in affinity-purified $\Lambda b_{\mathrm{SP} 1 \mid-1}$ diluted $1: 25$, affinity-purified $A b_{\mathrm{SPII-II}}$ diluted 1:25, $A b_{\mathrm{SP} 20}$ diluted $1: 50$, or affinity-purified $A b_{\mathrm{SP} 32-\mathrm{III}}$ diluted 1:25 for $1 \mathrm{hr}$ at room temperature followed by $36 \mathrm{hr}$ at $4^{\circ} \mathrm{C}$. All antisera were diluted in $0.05 \mathrm{~m}$ phosphate-buffered saline (PBS) containing $0.1 \%$ Triton X-100 and $1 \%$ normal goat serum. The sections were then treated as follows: rinsed for $1 \mathrm{hr}$ at room temperature in PBS containing $0.1 \%$ Triton $X-100$, incubated in goat anti-rabbit $\lg ($ diluted $1: 30$ for $1 \mathrm{hr}$ at $37^{\circ} \mathrm{C}$, rinsed for $1 \mathrm{hr}$ in PBS containing $0.1 \%$ Triton X-100 at room temperature, incubated in rabbit PAP diluted $1: 100$ for $1 \mathrm{hr}$ at $37^{\circ} \mathrm{C}$, rinsed in PBS for $15 \mathrm{~min}$, rinsed for $5 \mathrm{~min}$ in $\mathrm{PB}$, rinsed in $\mathrm{TB}(0.1 \mathrm{M}$ Tris- $\mathrm{HCl}[\mathrm{pH} 7.4])$, treated with $0.4 \%$ diaminobenzidine and $0.003 \% \mathrm{H}_{2} \mathrm{O}_{2}$ in TB for $10 \mathrm{~min}$, rinsed in TB for $10 \mathrm{~min}$, and rinsed in $\mathrm{PB}$ for $10 \mathrm{~min}$. The sections were mounted on subbed glass slides, air dried, dehydrated, cleared in xylene, and coverslipped. A Leitz Dialux research microscope was used to examine and photograph the sections.

Immunocytochemical controls included replacing the primary antisera with either normal rabbit serum or no serum at all. Under these conditions, there was no discrete staining of cells, fibers, or terminals in control sections, and only a light background density was observed.

\section{Results}

\section{Anti-peptide antibodies}

We have used anti-peptide antibodies directed against both conserved and subtype-specific amino acid sequences of $\mathrm{Na}^{+}$channels. $A b_{\mathrm{Sp}_{20}}$ is directed against residues $1106-1126$ of type II or IIA $\mathrm{Na}^{+}$channel $\alpha$-subunit; only two conservative substitutions are present in the corresponding type I and type III sequences. $\mathrm{Ab}_{\mathrm{SP} 20}$ has previously been shown to recognize both type $\mathrm{I}$ and type II or IIA $\mathrm{Na}^{+}$channels (Westenbroek et al., 1989), and we have used it in this study to determine the overall distribution of immunoreactive $\mathrm{Na}^{+}$channels.

$\mathrm{Ab}_{\mathrm{SP} 11-1}$, directed against a synthetic peptide corresponding to residues $465-481$ of type I, recognizes type I but not type II or IIA $\mathrm{Na}^{+}$channels in biochemical studies (Gordon et al., 1987) and selectively stains cell bodies of major projection neurons in the brain (Westenbroek et al., 1989). $\mathrm{Ab}_{\mathrm{SP} 1 /-11}$, directed against a synthetic peptide corresponding to residues $467-486$ of type II or IIA, recognizes type II anad IIA but not type I $\mathrm{Na}^{+}$channels in biochemical studies (Gordon et al., 1987) and selectively stains unmyelinated fiber layers in the brain (Westenbroek et al., 1989). Because type IIA $\mathrm{Na}^{+}$channcls differ from type II at only six scattered amino acid residues (Auld et al., 1988; Sarao et al., 1991), they cannot be distinguished from type II by available immunochemical reagents. Therefore, we refer to these two closely related channel subtypes collectively as type II in this work. We have also used antipeptide antibodies directed against SP32 III corresponding to residues 511-524 of type III $\mathrm{Na}^{+}$channels, a sequence in the intracellular loop between domains I and II that is not conserved in the type I or type II $\mathrm{Na}^{+}$channels, to detect type III $\mathrm{Na}^{+}$channels.

\section{Distribution of $\mathrm{Na}^{+}$channels in wild-type and shiverer mouse brain}

The distribution of $\mathrm{Na}$ ' channels in sagittal sections of brains of wild-type and shiverer mice is illustrated in Figure 1, $A$ and $B$. $\mathrm{Ab}_{\mathrm{SP} 20}$, which recognizes a conserved intracellular region of the $\mathrm{Na}^{+}$channel, shows a similar pattern of staining in mouse and rat brain (Fig. 1; Westenbroek et al., 1989). All gray matter regions are labeled, including the neocortex, hippocampus, basal ganglia, thalamus, nuclear regions of the brain stem, and cerebellar cortex, but no specific staining is observed in the myelinated tracts. In contrast, there is dense staining of both gray matter and hypomyelinated fiber tracts in white matter in the shiverer mouse $\mathrm{CNS}$ using $\mathrm{Ab}_{\mathrm{SP} 20}$ (Fig. $1 B$ ). At this low magnification, dense immunoreactivity can be observed in several major hypomyelinated tracts, including the anterior corpus callosum, the nigrostriatal path, and the internal capsule (Fig. $1 B$ ). Other fiber tracts in mutant mice with noticeably higher levels of staining for $\mathrm{Na}^{+}$channels include the fimbria, fornix, and corpus medullare of the cerebellum (see below), as well as the ascending and decussating pathways of the brainstem and the cerebellar peduncles. Except for these differences in staining of hypomyelinated tracts, the pattern and level of $\mathrm{Ab}_{\mathrm{SP} 20} \mathrm{immu-}$ noreactivity are similar in the gray matter regions of wild-type and shiverer mice. The increased antibody staining of $\mathrm{Na}^{+}$channels in hypomyelinated fiber tracts in the shiverer mouse correlates well with previous studies showing increased ${ }^{3} \mathrm{H}$-saxitoxin binding to $\mathrm{Na}^{+}$channels in the same pathways (Noebels et al., 1991).

Other sagittal sections were stained with $A b_{\mathrm{SP} 11-\mathrm{I}}, A \mathrm{~b}_{\mathrm{SP} 11-\mathrm{II}}$, or $\mathrm{Ab}_{\mathrm{SP32-11}}$ to determine whether type I, type II, or type III $\mathrm{Na}^{+}$ channels are responsible for the increased density of $\mathrm{Na}^{+}$channels observed with $A b_{\mathrm{SP} 20}$. Staining with these three antibodies revealed elevated immunoreactivity only for the type II $\mathrm{Na}^{+}$ channels (Fig. $1 C, D$ ). In the wild-type, type II $\mathrm{Na}^{+}$channels are observed in gray matter regions, but not in myelinaled lracts, in a pattern that is similar to $A b_{S P 20}$ immunoreactivity in mice and both $\mathrm{Ab}_{\mathrm{SP} 20}$ and $\mathrm{Ab}_{\mathrm{SP} 11-11}$ immunoreactivity in adult rats (Fig. $1 C$; Westenbroek et al., 1989). In the shiverer mouse (Fig. 1D), the pattern of type II immunoreactivity is identical to the pattern of immunoreactivity observed in the normal mouse except for relatively dense staining in hypomyelinated tracts such as the corpus callosum, internal capsule, and nigrostriatal pathway (Fig. $1 D$ ). Relatively dense type II immunoreactivity was also observed in the fimbria, fornix, and corpus medullare of the cerebellum (see below). There was no detectable difference in the pattern of staining observed using antibodies directed against type I or type III $\mathrm{Na}^{+}$channels between wild-type and mutant mice, indicating that the increase in $\mathrm{Na}^{+}$channel number in shiverer is due to an increase in type II channels. Only a light overall background staining was observed when the sections 
were incubated with nonimmune rabbit serum or in the absence of primary antibody, and no structures or regions showed specific staining (Fig. $1 E$ ).

\section{Corpus callosum and corticofugal fibers}

To compare the localization of the three $\mathrm{Na}^{+}$channel subtypes in fiber tracts of normal and mutant mice at higher resolution, selected forebrain pathways were examined in more detail. The corpus callosum, a collection of myelinated fibers that connect the neocortical hemispheres, shows differential staining between wild-type and shiverer mice (Fig. $2 A-H$ ). There is no detectable staining of $\mathrm{Na}^{+}$channels in the corpus callosum of normal mice with the antibodies $\mathrm{Ab}_{\mathrm{SP} 20}, \mathrm{Ab}_{\mathrm{SP} 11-1}, \mathrm{Ab}_{\mathrm{SPII-1I}}$, or $\mathrm{Ab}_{\mathrm{SP} 32-\mathrm{III}}$ (Fig. $2 A, C, E, G$, respectively). However, in shiverer mice there is relatively dense staining of the callosal fibers with $\mathrm{Ab}_{\mathrm{SP} 20}$ (Fig. $2 B$ ) or $\mathrm{Ab}_{\mathrm{SP} 11-\mathrm{II}}$ (Fig. $2 D$ ) but not with $\mathrm{Ab}_{\mathrm{SPII-1}}$ (Fig. $2 F$ ) or $\mathrm{Ab}_{\mathrm{SP} 32-\mathrm{III}}$ (Fig. $2 H$ ).

Corticofugal and corticopedal bundles of myelinated fibers that traverse the caudate were also observed to have increased staining in shiverer mice as compared to unaffected littermates. Using $A b_{\mathrm{SP}_{20}}, \mathrm{Ab}_{\mathrm{SP} 11-1}, \mathrm{Ab}_{\mathrm{SP} 11-\mathrm{II}}$, or $\mathrm{Ab}_{\mathrm{SP} 32-\mathrm{III}}$, no immunoreactivity was observed in these fiber bundles in wild-type mice (Fig. $2 A, C, E, G$, respectively). In shiverer mice, $\mathrm{Na}^{+}$channels immunoreactive with $\mathrm{Ab}_{\mathrm{SP} 20}$ (Fig. $2 B$ ) and $\mathrm{Ab}_{\mathrm{SP} 11-11}$ (Fig. $2 D$ ) were clearly localized in the hypomyelinated fiber bundles of the caudate. As in wild-type mouse brain, there was no staining present in these regions of shiverer mouse brain with $\mathrm{Ab}_{\mathrm{SP11-1}}$ or $\mathrm{Ab}_{\text {SP32-III }}$ (Fig. 2F,H, respectively). Thus, the increase in $\mathrm{Na}^{+}$ channel density is specific for type II in the corpus callosum and descending fiber bundles.

\section{Fornix and internal capsule}

Other forebrain pathways in which there are detectable differences in the pattern of immunoreactivity for $\mathrm{Na}^{+}$channels between wild-type and shiverer mice include the alveus of the hippocampus as well as the fimbria, fornix, and internal capsule. As in the regions described above, we only observed differences in the pattern of immunoreactivity using $\mathrm{Ab}_{\mathrm{SP} 20}$ and $A \mathrm{~b}_{\mathrm{SP} 1-11}$ (Fig. 3A-D). No differences were observed using type I- or type III-specific antibodies (not shown).

In wild-type mice, type II $\mathrm{Na}^{+}$channels were present primarily in unmyelinated fiber tracts. The hippocampal mossy fibers, which project from the dentate granule cells to the stratum lucidum and form synapses on the apical dendrites of pyramidal cells in CA2 and CA3 regions, stained the most intensely. Dense immunoreactivity is observed in the stratum oriens and stratum radiatum, but there is an absence of discrete staining of neuronal somata in the strata moleculare of the hippocampus and dentate gyrus, and in the myelinated fiber pathways in the alveus, fimbria, and fornix by type II-specific antibodies (Fig. $3 A$ ). In shiverer mice, the pattern of immunoreactivity for type II $\mathrm{Na}^{+}$channels is identical to wild-type except there is relatively dense immunoreactivity in the alveus, fimbria, and fornix (Fig. 3B). Myelinated efferent axons of pyramidal cells transverse the stratum oriens, collect on the surface of the hippocampus as the alveus, and leave the hippocampal formation in the fimbria and fornix. Of the three subtype-specific antibodies, only $\mathrm{Ab}_{\mathrm{SPI} \text { IIII }}$, which recognizes type II $\mathrm{Na}^{+}$channels, densely stains the hypomyelinated fibers in the alveus and fimbria-fornix of the shiverer mouse.

A dramatic difference in the pattern of type II $\mathrm{Na}^{+}$channel
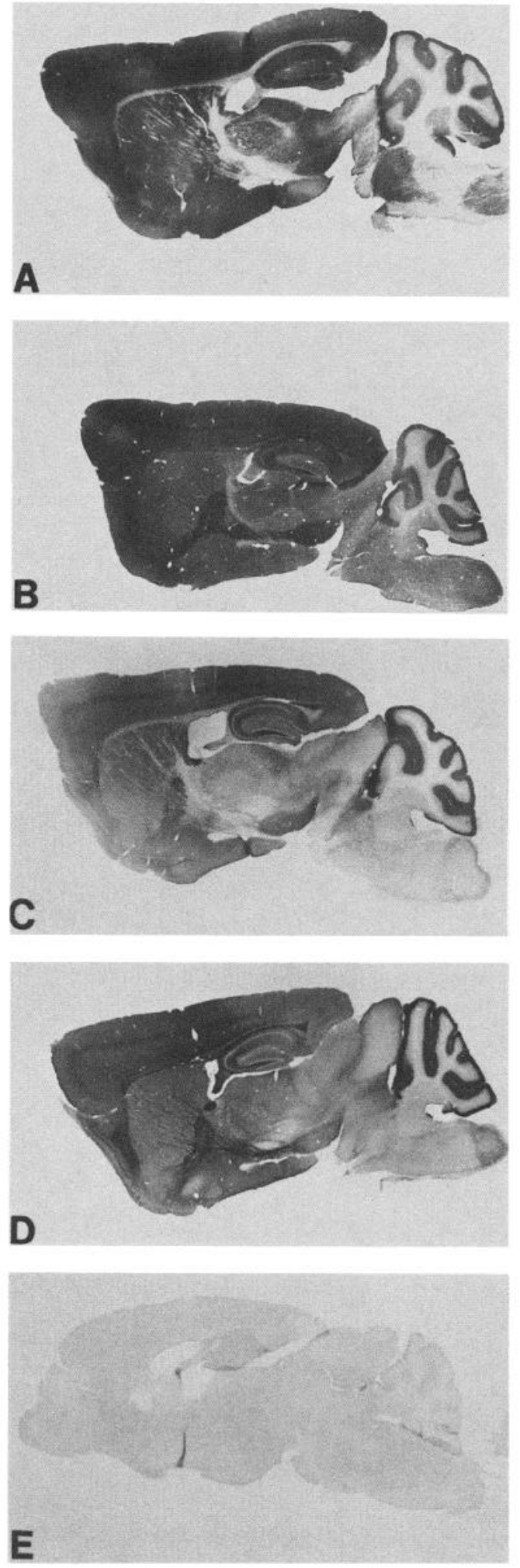

Figure 1. Overall localization of total $\mathrm{Na}^{+}$channels and type II $\mathrm{Na}^{+}$ channels in wild-type and shiverer mice. Sagittal sections of mouse brain were stained by the PAP method as described in Materials and Methods. $A, \mathrm{Ab}_{\mathrm{SP} 20}$ in wild-type; $B, \mathrm{Ab}_{\mathrm{SP} 20}$ in shiverer, $C, \mathrm{Ab}_{\mathrm{SP} 11-11}$ in wild-type; $D$, $\mathrm{Ab}_{\mathrm{SP} 1-\mathrm{II}}$ in shiverer; $E$, control section. Magnification, $7.6 \times$. 

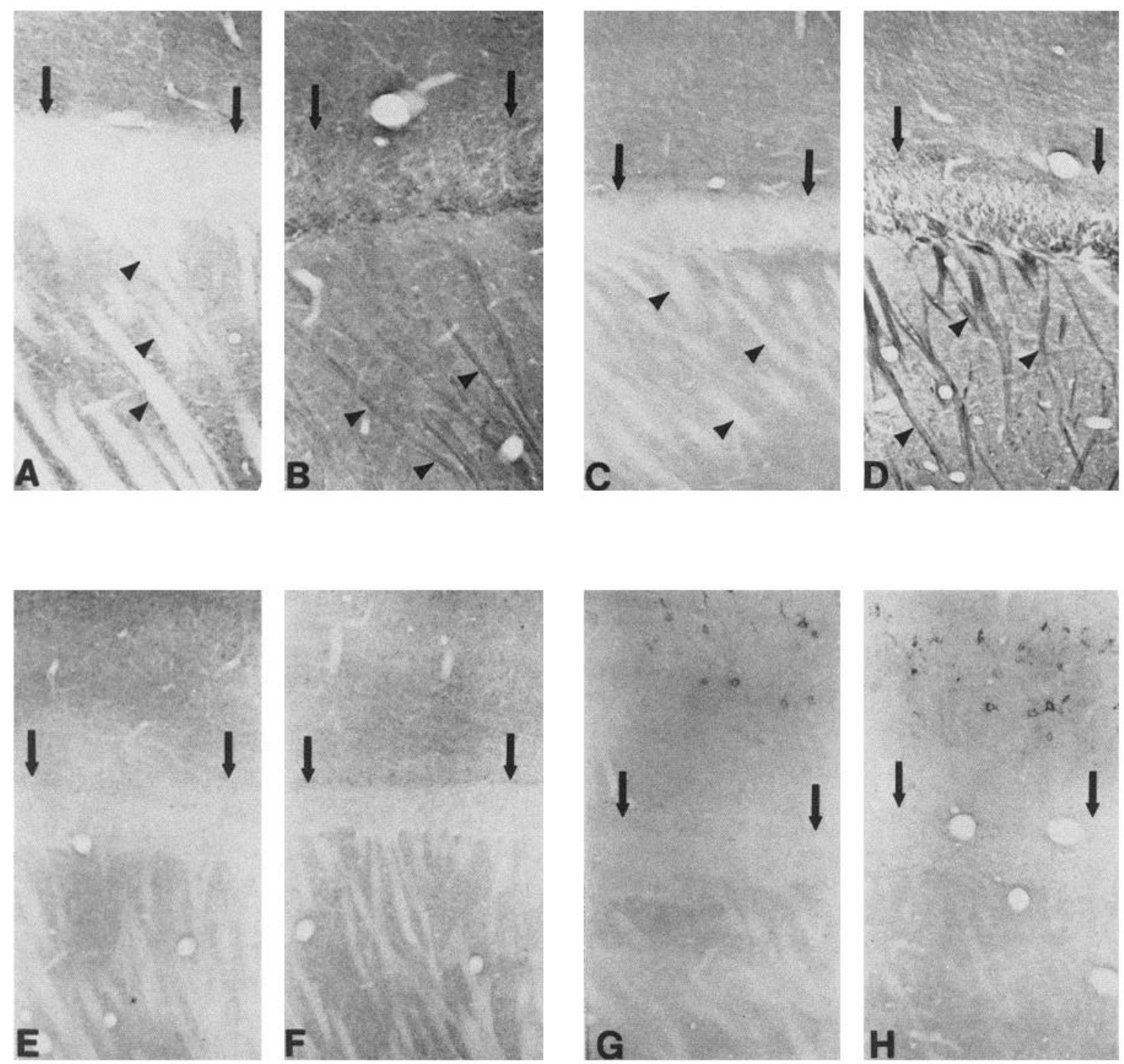

Figure 2. Localization of $\mathrm{Na}^{+}$channel types I, II, and III in corpus callosum and corticofugal fibers. Sagittal sections of wild-type and shiverer brain were stained with $\mathrm{Ab}_{\mathrm{SP} 20}$ and subtype-specific antibodies by the PAP method as described in Materials and Methods. $A$, wild-type stained with $\mathrm{Ab}_{\mathrm{SP} 20} ; B$, shiverer stained with $\mathrm{Ab}_{\mathrm{SP} 20} ; C$, wild-type stained with $\mathrm{Ab}_{\mathrm{SP11-11}} ; D$, shiverer stained with $A b_{\mathrm{SP11-11}} ; E$, wild-type stained with $\mathrm{Ab}_{\mathrm{SPII-1}} ; F$, shiverer stained with $\mathrm{Ab}_{\mathrm{SPII-1}} ; G$, wild-type stained with $\mathrm{Ab}_{\mathrm{SP} 32-\mathrm{III}} ; H$, shiverer stained with $\mathrm{Ab}_{\mathrm{SP} 32-\mathrm{III}}$. Arrows point to corpus callosum; arrowheads, to corticofugal fibers. Magnification, $67 \times$.

immunoreactivity in wild-type and shiverer mice is also observed in the internal capsule (Fig. $3 C, D$ ). Using $\mathrm{Ab}_{\mathrm{SP} 20}$, there is dense staining of hypomyelinated fiber bundles in the internal capsule in shiverer, but no staining in wild-type. This increase in $\mathrm{Na}^{+}$channel density is type II specific (Fig. $3 C, D$ ), since there is strong staining using $\mathrm{Ab}_{\text {SPII-II }}$ but no detectable staining of the internal capsule in shiverer mice using $\mathrm{Ab}_{\mathrm{SP} 11-\mathrm{I}}$ or $\mathrm{Ab}_{\mathrm{SP} 32-\mathrm{III}}$ (not shown).

\section{Cerebellum}

In the cerebellum, more subtle differences are observed in $\mathrm{Na}^{+}$ channel localization between shiverer and wild-type mice. In wild-type, $\mathrm{Ab}_{\mathrm{SP} 20}$ gives dense, homogeneous staining of the molecular layer (Fig. $4 A$ ), which is composed of Purkinje cell dendrites among a dense meshwork of interneurons and unmyelinated parallel fibers that form synapses upon them. A less dense but similarly homogeneous pattern of immunoreactivity is ob- served in the granular layer, which contains granule cells and the axons of Purkinje cells. The corpus medullare, the underlying white matter that contains myelinated afferent and efferent inputs to the cerebellum, does not stain with $A b_{S P 20}$ in wild-type. In the shiverer mouse, the pattern of staining with $\mathrm{Ab}_{\mathrm{SP} 20}$ in the molecular and granular layers remains unchanged, but the corpus medullare shows increased immunoreactivity to $\mathrm{Ab}_{\mathrm{SP} 20}$ with an intensity virtually identical to that observed for the granular layer (Fig. $4 B$ ). This elevated density of $\mathrm{Na}^{+}$channels in the hypomyelinated tracts in the cerebellum is also subtype specific. While staining of the molecular and granular layers with $\mathrm{Ab}_{\mathrm{SP11-II}}$ is unaltered by the shiverer mutation, the corpus medullare is unstained in wild-type mice but shows an increased intensity of staining that is similar to the granular layer in shiverer mice (Fig. $4 C, D$ ). The pattern of immunoreactivity in all layers of the cerebellum is identical in shiverer and normal mice when $\mathrm{Ab}_{\mathrm{SPI} 1-\mathrm{I}}$ or $\mathrm{Ab}_{\mathrm{SP} 32 \mathrm{III}}$ is used (Fig. $4 E-H$ ), indicating no 

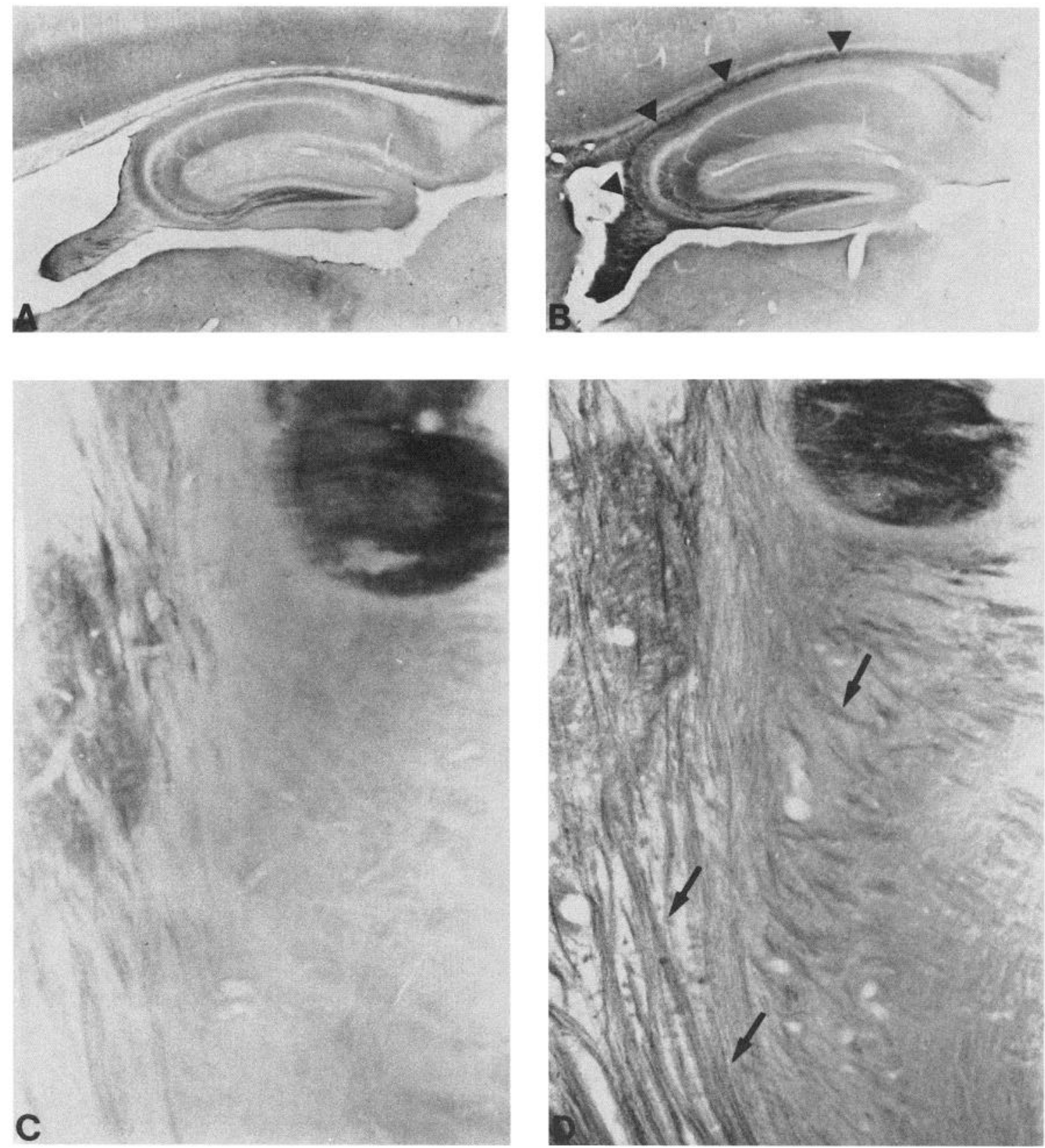

Figure 3. Localization of type II Na+ channels in hippocampus and internal capsule. Sagittal sections of wild-type and shiverer mouse brain stained with type II-specific antibody by the PAP method as described in Materials and Methods. A, Hippocampal region stained with $\mathrm{Ab}_{\mathrm{SPII-II}}$ in wildtype; $B, \mathrm{Ab}_{\mathrm{SPII-II}}$ staining of hippocampus in shiverer demonstrating labeling of alveus, and fimbria-fornix (arrowheads); $C$, wild-type stained with $\mathrm{Ab}_{\mathrm{SP} 11-\mathrm{II}}$ demonstrating lack of staining in the internal capsule; $D$, shiverer stained with $\mathrm{Ab}_{\mathrm{SP11-11}}$ demonstrating type II-immunoreactive fibers in the internal capsule (arrows). Magnification: $A$ and $B, 18 \times ; C$ and $D, 87 \times$.

increase in staining in the white matter for $\mathrm{Na}^{+}$channel subtypes I or III. Thus, hypomyelinated fiber pathways in the shiverer cerebellum show a specific elevation in type II $\mathrm{Na}^{+}$channels as observed in other regions of the brain.

\section{Cellular location of increased $\mathrm{Na}^{+}$channel density}

Close inspection of staining patterns for $\mathrm{Ab}_{\mathrm{SP} 20}$ and $\mathrm{Ab}_{\mathrm{SP} 11-\mathrm{II}}$ in coronal sections of the corpus callosum (not shown) and in the internal capsule (Fig. 3) and caudate (Fig. 2) reveals a fibrous pattern consistent with $\mathrm{Na}^{+}$channel localization in the hypomyelinated axons in these regions. Patterns suggesting enhanced staining of astrocytes and oligodendrocytes in hypomyelinated tracts were not observed. These results support the conclusion that the increased density of $\mathrm{Na}^{+}$channels we have observed represents channels that are localized in neurons.

\section{Discussion}

Elevated expression of $\mathrm{Na}^{+}$channels in hypomyelinated axons of shiverer mice

Our immunocytochemical results confirm and extend the conclusion from the previous saxitoxin-binding studies of Noebels et al. (1991) that there is an increased number of $\mathrm{Na}^{+}$channels 

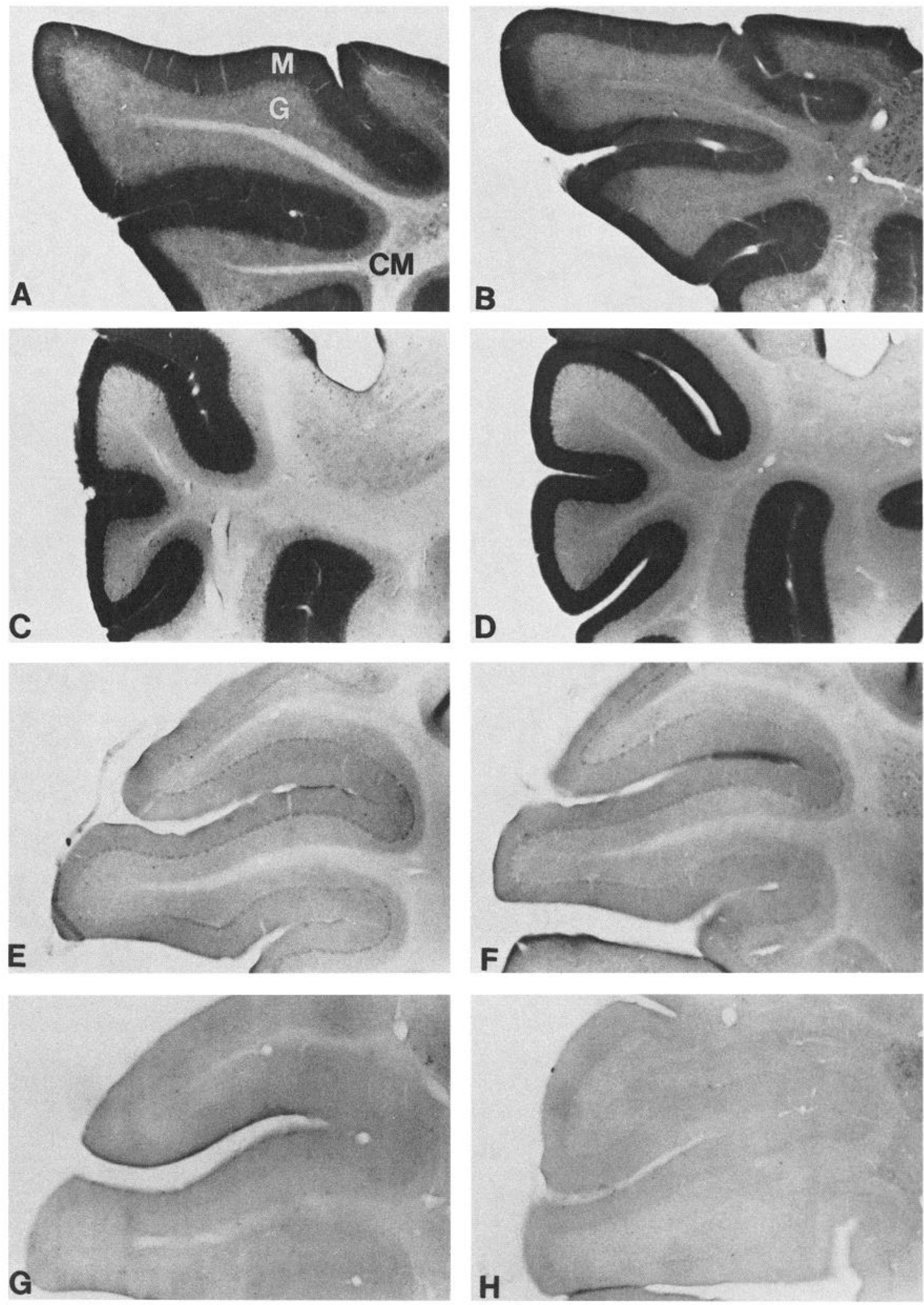

Figure 4. Localization of $\mathrm{Na}^{+}$channel types I, II, and III in cerebellum. Sagittal sections of wild-type and shiverer mouse brain were stained with the PAP method as described in Materials and Methods. $A$, Wild-type section stained with $\mathrm{Ab}_{\mathrm{sp} 20} ; B$, shiverer section stained with $\mathrm{Ab} \mathrm{b}_{\mathrm{sp} 20}$; $C$, wildtype section stained with $\mathrm{Ab}_{\mathrm{SPII-II}} ; D$, shiverer section stained with $\mathrm{Ab}_{\mathrm{SPII-1I}} ; E$, wild-type section stained with $\mathrm{Ab}_{\mathrm{SP11-1}} ; F$, shiverer section stained with $\mathrm{Ab}_{\mathrm{SP} 11-1} ; G$, wild-type section stained with $\mathrm{Ab}_{\mathrm{SP} 32-\mathrm{II}} ; H$, shiverer section stained with $\mathrm{Ab}_{\mathrm{SP} 32-\mathrm{II}} . G$, granular layer; $M$, molecular layer; $C M$, corpus medullare of the cerebellum. Magnification, $30 \times$. 
in the hypomyelinated fiber tracts in the brains of shiverer mice. Using the generally reactive antibody $A b_{\mathrm{SP} 20}$, we found a widespread increase in staining intensity of the major hypomyelinated tracts, including the corpus callosum, nigrostriatal tract, corticofugal and corticopedal fibers of the caudate, the internal capsule, the fimbria and fornix, and the corpus medullare of the cerebellum. The greater resolution of the immunocytochemical method of localization provides direct evidence that the increased $\mathrm{Na}^{+}$channel density is confined primarily to the hypomyclinated axons themselves. In regions with large-caliber axons or discrete axon bundles that are well resolved in the light microscope, sharply increased immunostaining of fibrous structures is observed while increased immunostaining of astrocytes or oligodendrocytes is not. To examine this point further, we localized type II $\mathrm{Na}^{+}$channel mRNA in normal and mutant mouse brain with cRNA probes complementary to the $5^{\prime}$ untranslated region (R. E. Westenbroek, J. L. Noebels, and W. A. Catterall, unpublished observations). Both wild-type and shiverer mouse brain showed substantial hybridization of these probes to neurons in the hippocampal region and cerebral cortex, but no specific hybridization to oligodendrocytes or astrocytes in the corpus callosum was observed in either normal or mutant animals. These preliminary results from in situ hybridization provide additional support for the conclusion that the increased expression of type II $\mathrm{Na}^{+}$channels reflects an increase in channel density in the hypomyelinated tracts in the shiverer brain. Evidently, the lack of myelination of shiverer axons causes an increased density of $\mathrm{Na}^{+}$channels in them. The presence of a high density of $\mathrm{Na}^{+}$channels in hypomyelinated axons may reduce the threshold for action potential initiation and contribute to the hyperexcitable phenotype of these mice.

\section{The density of type II $\mathrm{Na}^{+}$channels is increased in} hypomyelinated shiverer axons

The main finding of the present study is that the increased $\mathrm{Na}^{+}$ channel density in the hypomyelinated axons of shiverer mice is primarily due to a specific increase in type II $\mathrm{Na}^{+}$channels. Of three subtype-specific antibodies studied, only $\mathrm{Ab}_{\mathrm{SP11-II}}$ gave increased immunostaining of the hypomyelinated axons in shiverer mouse brain. Other studies have shown that type II $\mathrm{Na}^{+}$ channels are preferentially localized in axons while types I and III are preferentially localized in cell bodies (Westenbroek et al., 1989; R. E. Westenbroek and W. H. Catterall, unpublished observations). Thus, our present results indicate that the failure of myelination in shiverer axons causes a specific increase in the density of type II $\mathrm{Na}^{+}$channels, which are normally targeted to axons. $\mathrm{Na}^{+}$channel subtypes that are not normally targeted to axons are not measurably affected.

\section{Regulation of expression and localization of type $\mathrm{II} \mathrm{Na+}$ channels}

Myelinated axons have functionally specialized nodal and internodal regions (Rosenbluth, 1988; Black et al., 1990). Large inward $\mathrm{Na}^{+}$currents can be measured only at nodes of Ranvier (Brismar, 1980; Hille, 1984). Both electrophysiological measurements and measurements of numbers of saxitoxin binding sites indicate a high density of $\mathrm{Na}^{+}$channels in nodes of Ranvier (reviewed in Waxman and Ritchie, 1985; Black et al., 1990). Immunocytochemical experiments with $\mathrm{Na}^{+}$channel-specific antibodies confirm the high density of $\mathrm{Na}^{+}$channels at nodes (Ellisman and Levinson, 1982; Haimovich et al., 1984). In con- trast, there are few if any $\mathrm{Na}$ ' channels under the myelin because internodal regions of acutely demyelinated axons are not immunocytochemically stained with polyclonal antibodies against $\mathrm{Na}^{+}$channels (Ellisman and Levinson, 1982; Black et al., 1990) and only small $\mathrm{Na}^{+}$currents are recorded from acutely demyelinated internodal regions (Chiu and Ritchie, 1982; Shrager, 1987; reviewed in Black et al., 1990). Since $\mathrm{Na}^{+}$channels reach their membrane location in myelinated nerves by fast axonal transport (Lombet et al., 1985), this process may contribute to their restricted localization at nodes of Ranvier.

The number of neuronal $\mathrm{Na}^{+}$channels is also subject to strict regulation. Expression of $\mathrm{Na}^{+}$channels is strongly regulated during development of central neurons, increasing sharply during the postnatal processes of synapse formation and myelination and reaching a plateau level or declining in the mature animal (Gordon et al., 1987; Wollner et al., 1988; Beckh et al., 1989; Scheinman et al., 1989). The tissue-specific regulation of type II $\mathrm{Na}^{+}$channel expression depends on negative regulatory elements in $5^{\prime}$-flanking regions that prevent expression of the gene in non-neuronal cells (Maue et al., 1990). The factors that determine the time course of $\mathrm{Na}^{+}$channel gene expression in the developing brain are unknown, but previous studies of nerve and muscle cells in cell culture indicate that NGF can increase expression of $\mathrm{Na}^{+}$channel genes (Mandel et al., 1988) and electrical activity can reduce their expression (Offord and Catterall, 1989).

Our present results suggest a new mode of regulation of the number and localization of type II $\mathrm{Na}^{+}$channels. Evidently, both the localization of $\mathrm{Na}^{+}$channels at nodes of Ranvier and the density of type II $\mathrm{Na}^{+}$channels in myelinated axons are regulated by the process of myelination itself through interaction with the oligodendrocyte membrane or with myelin basic protein. Myelination may exert its effects through modulation of neuronal gene expression or through modulation of $\mathrm{Na}^{+}$channel biosynthesis, membrane targeting and insertion, or degradation. Alternatively, myelination may deny access of astroglial processes to the axonal membrane and thereby prevent an astroglial-dependent regulation of axonal $\mathrm{Na}^{+}$channels (Rosenbluth, 1988). Whatever the mechanism, this glial-dependent regulatory process may serve both to limit the number of type II $\mathrm{Na}^{+}$ channels in the axon and to help restrict $\mathrm{Na}^{+}$channel localization to nodes of Ranvier.

Our results do not define which $\mathrm{Na}^{+}$channel subtype is normally present at nodes of Ranvier. Nodes are not stained detectably at the light microscope level by any of our intracellularly directed anti-peptide antibodies, although control experiments with antibodies against neurofilament proteins show that our treatment of tissue allows antibody access to the intracellular compartment all along myelinated axons. Either the small size of central nodes of Ranvier prevents detection of their $\mathrm{Na}^{+}$ channels in the light microscope, or an unidentified $\mathrm{Na}^{+}$channel subtype is expressed there.

\section{Excitability of demyelinated axons}

Knowledge of dynamic changes in the distribution and function of ion channels along demyelinated fibers is required to understand their electrophysiological properties and is essential for an understanding of demyelinating diseases. Biochemical studies with ${ }^{3} \mathrm{H}$-saxitoxin and ${ }^{3} \mathrm{H}$-TTX have shown a higher density of channels in chronically demyelinated axons (Ritchie et al., 1981; Ritchie and Rang, 1983; Rieger et al., 1984). These stud- 
ics, combined with evidence from anatomical and physiological experiments in which the longitudinal current was measured along demyelinated axons (Rasminsky and Sears, 1972; Bostock and Sears, 1978; Smith and Hall, 1980; Smith et al., 1982; Waxman and Wood, 1984), suggest there is recruitment of $\mathrm{Na}^{+}$ channels following demyelination in normal animals. Our results with hypomyelinated axons of shiverer mice imply that these increases in $\mathrm{Na}^{+}$channel number following demyelination of normal central axons may also be due to a selective increase in the density of type II $\mathrm{Na}^{+}$channels in response to demyelination. Interventions that can induce an increase in the density of type II $\mathrm{Na}^{+}$channels in demyelinated fibers may dramatically improve impulse conduction in demyelinating diseases.

\section{References}

Auld VJ, Goldin AL, Krafte DS, Marshall J, Dunn JM, Catterall WA, Lester HA, Davidson N, Dunn RJ (1988) A rat brain $\mathrm{Na}^{+}$channel $\alpha$-subunit with novel gating properties. Neuron 1:449-461.

Barbarese E, Nielson ML, Carson JH (1983) The effect of the Shiverer mutation on myelin basic protein expression in homozygous and heterozygous mouse brain. I Neurochem 40:1680-1686.

Beckh S, Noda M, Lubbert M, Numa S (1989) Differential regulation of three sodium channel messenger RNAs in the rat central nervous system during development. EMBO J 8:3611-3616.

Bird TD, Farrell DF, Sumi SM (1978) Brain lipid composition of the shiverer mouse: (genetic defect in myelin development). J Neurochem 31:387-391.

Black JA, Kocsis JD, Waxman SG (1990) Ion channel organization of the myelinated fiber. Trends Neurosci 13:48-54.

Bostock $H$, Sears IA (1978) The internodal axon membrane: electrical excitability and continuous conduction in segmental demyelination. J Physiol (Lond) 280:273-301.

Bourre JM, Jacque C, Delassalle A, Nguyen-Legros J, Dumont O, Lachapelle F, Raoul M, Alvarez C, Baumann N (1980) Density profile and basic protein measurements in the myelin range of particulate material from normal developing mouse brain and from neurological mutants (Jimpy, Quaking, Trembler; Shiverer and its mld allele) obtained by zonal centrifugation. J Neurochem 35:458-464.

Brismar T (1980) Potential clamp analysis of membrane currents in rat myelinated nerve fibres. J Physiol (Lond) 298:171-184.

Chernoff GF (1981) Shiverer: an autosomal recessive mutant mouse with myelin deficiency. J Hered 72:128.

Chiu SY, Ritchie JM (1982) Evidence for the presence of potassium channels in the internode of frog myelinated nerve fibres. J Physiol (Lond) 322:485-501.

Costa MRC, Catterall WA (1984) Cyclic AMP-dependent phosphorylation of the $\alpha$ subunit of the $\mathrm{Na}^{+}$channel in synaptic nerve ending particles. J Biol Chem 259:8210-8218.

Dupouey P, Jacque C, Bourre JM, Cesselin F, Privat A, Baumann N (1979) Immunocytochemical studies of myelin basic protein in shiverer mouse devoid of major dense line of myelin. Neurosci Lett 12: $113-118$.

Ellisman MH, Levinson SR (1982) Immunocytochemical localization of sodium channel distribution in the excitable membrane of Electrophorus electricus. Proc Natl Acad Sci USA 79:6707-6711.

Gordon D, Merrick D, Auld V, Dunn R, Goldin AL, Davidson N, Catterall WA (1987) Tissue-specific expression of the $R_{1}$ and $R_{I I}$ sodium channel subtypes. Proc Natl Acad Sci USA 84:8682-8686.

Haimovich B, Bonilla E, Casadei J, Barchi R (1984) Immunocytochemical localization of the mammalian voltage dependent sodium channel using polyclonal antibodies against the purified protein. $\mathbf{J}$ Neurosci 4:2259-2268.

Hille B (1984) Ionic channels of excitable membranes. Sunderland, MA: Sinauer.

Kayano T, Noda M, Flockerzi V, Takahashi H, Numa S (1988) Primary structure of rat brain sodium channel III deduced from the cDNA sequence. FEBS Lett 228:187-194.

Kirschner DA, Ganser AL (1980) Compact myelin exists in the absence of basic protein in the Shiverer mutant mouse. Nature 283: 207-210.

Lombet A, Laduron P, Mourre C, Jocomet Y, Lazdunski M (1985)
Axonal transport of the voltage dependent $\mathrm{Na}^{+}$channel protein identified by its tetrodotoxin binding site in rat sciatic nerves. Brain Res 345:153-158.

Mandel G, Cooperman SS, Maue RA, Goodman RH, Brehm P (1988) Selective induction of brain type II $\mathrm{Na}^{+}$channels by nerve growth factor. Proc Natl Acad Sci USA 85:924-928.

Maue RA, Kraner SD, Goodman RH, Mandel G (1990) Neuronspecific expression of the rat brain type II sodium channel gene is directed by upstream regulatory elements. Neuron 4:223-231.

Merrifield RB (1963) Solid phase peptide synthesis. I. The synthesis of a tetrapeptide. J Am Chem Soc 85:2149-2154.

Molineaux SM, Engh H, de Ferra F, Hudson L, Lazzarini RA (1986) Recombination within the myelin basic protein gene created the dysmyelinating shiverer mouse mutation. Proc Natl Acad Sci USA 83: 7542-7546.

Noda M, Ikeda T, Kayano T, Suzuki H, Takeshima H, Kurasaki M, Takahashi H, Numa $S$ (1986) Existence of distinct sodium channel messenger RNAs in rat brain. Nature 320:188-192.

Noebels JL, Marcom PK, Jalilian-Tehrani MH (1991) Myelin basic protein gene deletion increases sodium channel density in hypomyelinated brain. Nature 352:431-434.

Offord J, Catterall WA (1989) Electrical activity, cAMP, and cytosolic calcium regulate mRNA encoding sodium channel alpha subunits in rat muscle cells. Neuron 2:1447-1452.

Orth DN (1979) Adrenocorticotrophic hormone. In: Methods of hormone radioimmunoassay (Jaffee BM, Behrman HR, eds), pp 245284. New York: Academic.

Peterson AC, Bray GM (1984) Hypomyelination in the peripheral nervous system of shiverer mice and in shiverer $\leftrightarrow$ normal chimaera. J Comp Neurol 227:348-356.

Privat A, Jacque C, Bourre JM, Dupouey P, Baumann N (1979) Absence of the major dense line in myelin of the mutant mouse 'shiverer.' Neurosci Lett 12:107-112.

Rasminsky M, Sears TA (1972) Internodal conduction in undissected demyelinated nerve fibres. J Physiol (Lond) 227:323-350.

Readhead C, Popko B, Takahashi N, Shine HD, Saavedra RA, Sidman RL. Hood L (1987) Expression of a myelin basic protein gene in transgenic shiverer mice: correction of the dysmyelinating phenotype. Cell 48:703-712.

Rieger I, Pincon-Raymond M, Lombet A, Ponzio G, Lazdunski M, Sidman R (1984) Paranodal dysmyelination and increase in tetrodotoxin binding sites in sciatic nerve of the motor endplate disease (med/med) of the mouse during postnatal development. Dev Biol 101:401-409.

Ritchie JM, Rang HP (1983) Extraneuronal saxitoxin binding sites in rabbit myelinated nerve. Proc Natl Acad Sci USA 83:2803-2807.

Ritchie JM, Rang HP, Pellegrino R (1981) Sodium and potassium channels in demyelinated and remyelinated mammalian nerve. $\mathrm{Na}$ ture 294:257-259.

Roach A, Takahashi N, Pravtcheva D, Ruddle F, Hood L (1985) Chromosomal mapping of mouse myelin basic protein gene and structure and transcription of the partially deleted gene in shiverer mutant mice. Cell 42:149-155.

Rosenbluth J (1980a) Peripheral myelin in the mouse mutant shiverer. J Comp Neurol 193:729-739.

Rosenbluth J (1980b) Central myelin in the mouse mutant shiverer. J Comp Neurol 194:639-648.

Rosenbluth J (1988) Role of gial cells in differentiation and function of myelinated axons. J Dev Neurosci 6:3-24.

Sarao R, Gupta GK, Auld VA, Dunn RJ (1991) Nucleic Acids Res 19:5673-5679.

Scheinman RI, Auld VJ, Goldin AL, Davidson N, Dunn RJ, Catterall WA (1989) Developmental regulation of sodium channel expression in the rat forebrain. J Biol Chem 264:10660-10666.

Shrager P (1987) The distribution of sodium and potassium channels in single demyelinated axons of the frog. J Physiol (Lond) 392:587602 .

Smith KJ, Hall SM (1980) Nerve conduction during peripheral demyelination and remyelination. J Neurol Sci 48:201-219.

Smith KJ, Bostock H, Hall SM (1982) Saltatory conduction precedes remyelination in axons demyelinated with lysophosphatidyl choline. J Neurol Sci 54:13-31.

Sternberger LA (1979) Immunocytochemistry, pp 104-169. New York: Wiley.

Waxman SG, Ritchie JM (1985) Organization of ion channels in the myelinated nerve fiber. Science 228:1502-1507. 
Waxman SG, Wood SL (1984) Impulse conduction in inhomogeneous axons: effects of variation in voltage sensitive ionic conductance on invasion of demyelinated axon segments and preterminal fibers. Brain Res 294:111-122.

Westenbroek RE, Merrick DK, Catterall WA (1989) Differential subcellular localization of the $R_{I}$ and $R_{1 I} \mathrm{Na}^{+}$channel subtypes in central neurons. Neuron 3:695-704.
Wollner DA, Scheinman R, Catterall WA (1988) Sodium channel expression and assembly during development of retinal ganglion cells. Neuron 1:727-737.

Yarowski PJ, Krueger BK, Olson CE, Clevinger EC, Koos RD (1991) Proc Natl Acad Sci USA 88:9453-9457. 